\title{
Vida Policial: compreensão civilizadíssima da repressão ao crime e (ou) influência na psycologia dos jovens
}

Elena Camargo Shizuno*

Resumo: Este trabalho analisa o conto e o folhetim policiais publicados na revista Vida Policial, editada na cidade do Rio de Janeiro (1925 a 1927). O semanário publicava crônica policial, conto, folhetim, doutrina policial, textos do mundo jurídico, bem como notícias jornalísticas. Os escritos policiais foram meios de construção de tipos de crime e criminoso, ao mesmo tempo foram produtores de um imaginário social que imputava a esse tipo de literatura o estigma de manual do crime. Nos escritos policiais, reproduzia-se o que chamamos de educação às avessas, principalmente de jovens e crianças, pois as ações e os personagens imprimiam com a marca do ilegalismo uma forma de combate social mais aceitável e eficaz. As ações e os meios de combate ao crime, vistos como modelo ideal, perpetrados por agentes de segurança amadores - os detetives diletantes -, implicam a potência individual do investigador, como Sherlock Holmes, que se consolidou como o super-herói, arquetípico, uma exemplaridade de vigilância, prevenção e segurança.

Palavras-chave: Revista policial. Crime e mídia. Folhetim policial.

\footnotetext{
* Universidade Tecnológica Federal do Paraná (UTFPR)/Centro de Estudos em Segurança Pública e Direitos Humanos (CESPDH-UFPR). E-mail: elena. shizuno@terra.com.br
} 
Vida Policial: compreensão civilizadíssima da repressão ao crime...

\section{Introdução}

A revista Vida Policial foi criada na cidade do Rio de Janeiro e editada entre os anos de 1925 a 1927, com o subtítulo bebdomadário noticioso, crítico e doutrinário. Tal designação ressaltava os seus obje$\infty$ tivos de publicar crônica policial, conto, folhetim, criminologia, ( ) textos do mundo jurídico e notícia jornalística, como veremos no decorrer deste trabalho.

Os motes da revista consistiam em "auxiliar a educação do povo e, ao mesmo tempo, fornecer meios para a sua defesa." Vida Policial também autodenominava-se "um jornal de educação social", "um órgão de defesa social", "única revista no gênero em todo o país". (VIDA POLICIAL, n. 80, 1926) Certamente, os motes referiam-se à autoclassificação do perfil da revista.

Em Vida Policial, a publicação do conto e do folhetim criminais, e mais especificamente a do tipo policial, ocupava longas páginas e, desde o seu surgimento, criou um público assíduo. Genericamente, publicaram-se o conto e o folhetim "criminais" contendo estórias de crimes, distintos dos intitulados "policiais" ou "de mistério" caracterizados pela existência do personagem investigador, o detetive policial. Porém, ocasionalmente, um poderia estar inserido no outro. (COSTA, 2002) Importante dizer que os contos e folhetins policiais publicados na revista eram classificados pelos seus editores como romance policial.

Acreditamos que esse tipo de escrito tornou midiáticos os elementos que a constituíam, tendo em vista os personagens, pelas temáticas e pelos modos de resolução dos crimes, principalmente para o universo urbano no Brasil da época, obviamente levando-se em conta as taxas de alfabetização de então. Em específico, o nosso objetivo é analisar o conto e o folhetim policiais publicados nesta revista, bem como compreender quais eram as formas de construção sobre o universo do crime e os criminosos presentes nestes escritos.

Neste artigo abordamos a relação do folhetim e do conto criminal/policial com a discussão presente no semanário Vida Policial sobre a função desse tipo de literatura, ora vista como negativa, ora vista como positiva, pois construía tipos de um polo e outro de personagens e modus operanti a seremem copiados pelos criminosos e pelos agentes da lei.

Anos 90, Porto Alegre, v. 21, n. 39, p. 257-284, jul. 2014 
Partimos da análise, do debate presente na revista sobre a valorização de autores centrais da ficção policial/criminal como Edgar Allan Poe e Arthur Conan Doyle e como a literatura policial pode ser considerada "manual do crime", com suas tensões e ambiguidades, além do cunho "pedagógico" e da cientificidade da ação investigativa.

\section{Literatura que fez escola: Poe, Conan Doyle e as referências clássicas}

Nos estudos sobre o tema, os historiadores de ficção detetivesca distinguem dois grupos ou "escolas" de autores que historicizam o gênero policial. Majoritário, o primeiro grupo sustenta que Edgar Allan Poe (1809-1849) é o pai fundador, e que histórias de detetive, em oposição às de mistério, somente poderiam existir se houvessem forças policiais e detetives, sendo que isso só foi possível no século XIX, quando surgiram os departamentos de investigação criminal em Londres e Paris. Para esses historiadores, importam mais os elementos da trama e da estrutura e menos o método do detetive.

Em contrapartida, o grupo minoritário enfatiza o método detetivesco, e não a existência de um crime e detetive; importa a esse grupo a ocorrência de dedução racional, e isso eles encontram na Bíblia, em Heródoto, bem como em Zadig, de Voltaire. Portanto, voltam-se para aquela que é considerada a questão central, que é o enigma. (ECO; SEBOK, 2004, p. 199-200) A título de exemplo, segundo Feinman, a primeira história de crime foi o caso bíblico de Caim e Abel, "tão velho quanto a própria literatura", mas, no caso bíblico, obviamente, não há detetive. (FEINMANN, 1975, p. 105).

Para Harrowitz, a polarização entre essas duas vertentes é problemática, pois torna precária a definição do gênero detetivesco, a sua história e a crítica ao trabalho de Poe. No primeiro caso, reduz-se a importância do método do detetive e no segundo agrupam-se genericamente autores que utilizam categorias lógicas e trabalham a partir da dedução racional. Para resolver parte dessas questões, a autora examinou o método detetivesco em Poe, considerado o 
Vida Policial: compreensão civilizadíssima da repressão ao crime...

primeiro exemplo de "inquirição abdutiva no contexto da fórmula detetive-crime"(HARROWITZ, 2004, p. 201) no sentido de uma forte presença do papel da intuição aliada à presença do conhecimento e da experiência em seus escritos.

Com efeito, os primeiros romances policiais foram escritos entre o século XIX ao final da Primeira Guerra Mundial, em 1918, e foram diretamente influenciados por Edgar Allan Poe (18091849). O espaço em que se desenvolviam as tramas, o cenário, era construído como os das ruas dos detetives Lecoq, do escritor Gaboriau (1832-1873) e de Sherlock Holmes, escrito por Arthur Conan Doyle. Nesse tipo de escrita, os assassinos têm relações com as classes perigosas, os pobres e criminalizados em geral.

O cânone literário considera Edgar Alan Poe como o autor paradigmático desse gênero. ${ }^{1} \mathrm{O}$ seu personagem principal, inspetor Dupin, personificará o tipo do detetive seguido por outros autores, como a existência de um companheiro, parceiro de investigação. Em 1841, publicou-se seu texto, Os crimes na rua Morgue (1841), considerado a primeira história policial moderna - curiosa e inesperadamente, neste caso, o assassino é um orangotango -, segundo Peter Haining "Poe criou a primeira grande detetive na ficção e em apenas cinco histórias estabeleceu as regras básicas para a história de detetive". (HAINING, 2002, p. 2) E, ainda,

Poe produziu um volume de trabalho que garantem o seu reconhecimento como provavelmente o maior escritor americano do século XIX e como "pai" do conto de detetive. Ele era um gênio, e sua obra prendeu a imaginação de gerações de leitores e de escritores de ficção de detetive. (Idem)

Também em Marshall Mc Luhan exalta-se o processo criativo do autor:

Foi Edgar Allan Poe que elaborou a razão dessa percepção última do processo poético e que viu que, em vez de direcionar a obra para o leitor, era necessário incorporar o leitor na obra. Tal era seu plano em "A filosofia da composição”. E, pelo menos, Baudelaire e Valéry, reconheram em 
Poe um homem da estatura de Leonardo da Vinci. Poe viu claramente que a antecipação do efeito era a unica forma de conseguir o controle orgânico do processo criador. (McLUHAN, 2003, p. 27).

O escritor Medeiros e Albuquerque o considera “o primeiro detetive digno desse nome, o pai das estórias policiais, primeiro herói do romance policial e fundador de um novo gênero." (ALBUQUERQUE, 1979, p. 128). Segundo Oscar Mendes, a sua influência no Brasil foi marcante. Machado de Assis traduziu $O$ corvo e, em dois dos seus contos, $O$ alienista e $O$ Cão de Lata ao Rabo, há influência de Poe; e serviu de inspiração em escritos de Monteiro Lobato. ${ }^{2}$ (MENDES, 1986, p. 56).

De modo sugestivo, um único conto de Poe publicado na revista Vida Policial intitulou-se O systema do Dr. Breu e do Prof. Penna. Nele um homem visita um hospício e é recebido pelo diretor e seus convidados à mesa. Porém, de modo assustador, é revelado a ele que, na realidade, todos eram pacientes do hospital em rebelião e que os guardas estavam enclausurados como os loucos. ${ }^{3}$ Este famoso conto de Poe foi publicado pela primeira vez no ano de 1845, na Graham's Lady's and Gentleman's Magazine, originalmente com o título de The System of Dr. Tarr and Prof. Fether.

Oscar Mendes esclarece que o sistema aludido refere-se a uma forma de punição que existiu nos EUA em "[...] que consistia em cobrir de penas os condenados, fato que se designava pela expressão to tar and feather somebory." (POE, 1986, p. 608) No prefácio que faz à edição intitulada Fiç̧ão completa, poesia e ensaios, publicado pela editora Nova Aguilar, diz que este é um conto bumorístico, e complementa "Assim é que organizamos toda a obra em seções de acordo com os vários gêneros em que se exercitou a versatilidade intelectual e criadora de Edgard Alan Poe." (Ibid., p.13).

$\mathrm{Na}$ revista, em matéria intitulada $O$ gênio tenebroso, uma das alcunhas recorrentes de Edgar Allan Poe, foi citado como aquele cujas "obras impressionam, enchem de horror e é tal característico do seu todo que consegui (sic) ellas formar uma escola". Esse texto, publicado em 1925, sem assinatura, discorreu sobre algumas questões centrais sobre a figura do autor do romance policial e sobre o escrito policial. ${ }^{4}$ 
Vida Policial: compreensão civilizadíssima da repressão ao crime...

A matéria de uma página e muitas imagens dava ênfase ao pavoroso no texto de Poe e a sua própria vida. Exemplo do entrecruzamento da vida e da obra, Poe era a própria imagem do pavor, "o mais desgraçado dos poetas", cuja "vida miserável de tédio e de tristezas achava-se impressa em cada página das suas produções"5. A matéria assim referia-se ao autor: "[...] o desventurado escriptor era um tarado e não podia ser de outra maneira, pois que filho de paes alcoólicos, necessariamente, havia de aguentar com o vicio originário", cuja hereditariedade o perseguiu até a morte. "Poeta das trevas", conforme a matéria, consciente de sua pena viveu só e morreu pobre, pois suas produções não o mantinham, tanto que se tornou soldado, "a farda, porém, lhe pesava. Atirou-a fora e, de novo, lançou-se na litteratura tenebrosa. Ninguém como elle soube juntar o pavoroso com tintas mais carregadas".

Hereditariedade e gênio tenebroso combinavam-se numa figura que era a própria expressão de sua fatalidade. Essa caracterização tipificava a degenerescência, teoria francesa do século XIX esboçada por Morel, retomada e difundida por Lombroso e adotada pela medicina legal. Essas ideias influenciaram as práticas eugênicas, a criminologia e a antropologia e fundamentaram a noção da transmissão de uma tara "hereditária", sendo princípio de um saber médico sobre a loucura e a anormalidade no século XIX. ${ }^{7}$ (FOUCAULT, 1999. p. 301) Na expressão de Darmon:

Estigmatizado pelo discurso médico, "popularizado" pelo teatro e pelo romance, o degenerado torna-se a partir de então um pária indigno de uma época na qual a medicina e a higiene estão triunfando. À margem da higiene propriamente dita, que elimina o perigo de infecções, da higiene social, que se empenha em fazer regredir os fatores sociais de propagação da doença e da delinqüência, entra em cena um rebento das ciências médicas infinitamente menos glorioso: a higiene racial. (DARMON, 1991, p. 194-197; CARRARA, 1998. p. 81-89). 
Em 1926, essas eram questões que pautavam o editorial da revista Vida Policial, assim como parte dos contos e folhetins policiais publicados pelo hebdomadário. A campanha contra o álcool acompanhava a discussão norte-americana sobre a questão, além do combate ao jogo do bicho, à prostituição e cafetinagem, que dominavam grande parte das discussões do hebdomadário. De modo destacado no semanário, Poe era o gênio tenebroso que descreveu Lombroso, pois sua vida e sua obra inter-relacionavam-se: se não fez tudo o que escreveu, ao menos ele vivenciou a loucura e a decadência humanas. A sua imaginação era paralela aos acontecimentos trágicos que o moldavam, sendo ele um indivíduo propenso já que o mal da tara hereditária o acompanhou.

Obviamente, mesmo que Poe não tenha cometido os crimes que escreveu, a relação entre o seu grau de propensão nata à autodestruição, via alcoolismo, impunha-lhe a condição de degenerado. O que caminhava par a par com a condição de gênio do tenebroso do que a revista intitulava de romance policial, expressada na diversidade dos modos e meios de suas tramas, que o tornaram o fundador de uma escola, intitulada pela revista "manual do crime", aquela que ensinava a ser bandido pelo mau exemplo. Isso, mesmo que os seus enredos e suas tramas - nem todas, no caso deste autor - tivessem um "final feliz".

$\mathrm{Na}$ revista Vida Policial, houve também muitas referências ao personagem central construído por Arthur Conan Doyle, que capturaram a simbologia e um imaginário sobre o detetive Sherlock Holmes. Ao longo de sua existência, o hebdomadário publicou quatro estórias em oito números, desse detetive, sendo uma delas o Funil de Couro, categorizada como gênero de terror e mistério.

$\mathrm{Na}$ ficção, Doyle construiu um personagem que espelha a possibilidade de um indivíduo deduzir logicamente ao extremo, pois, sempre exato e capaz, solucionava os crimes a partir da observação e no perfeito encadeamento dos fatos, levando ao máximo a possibilidade da ciência dedutiva.

Assim também para revista, a grande referência do escrito policial é aquele apontado diversas vezes como sinônimo de ideal de investigador, o detetive Sherlock Holmes. Para um de seus admiradores e estudiosos, Edgard W. Smith: 
Vida Policial: compreensão civilizadíssima da repressão ao crime...

Holmes ergue-se diante de nós como um símbolo [...] de tudo que não somos mas sempre teríamos desejado ser [....] Nos o vemos como a expressão acabada de nosso anseio por esmagar o mal e corrigir os erros de que o mundo está infestado.. [Ele] é a personificação de algo em nós que perdemos ou nunca tivemos. [...] Esse é o Sherlock Holmes que amamos - o Holmes implícito e eterno em nós mesmos. (KLINGER, Leislie, 2005, p. 16 Apud DOYLE, 2005, p. 16).

O personagem Sherlock Holmes é considerado exemplo de honestidade, obstinação, pertinência, humanitarismo e excentricidade. É o superdetetive - melhor que a polícia - que reflete uma tendência antiautoritária do pensamento anglo-americano e uma visão liberal, na concepção de Feinmann, nele está presente a ideia de competência do cidadão comum, típica dos ingleses: "Mais do que na América, onde nos interessamos por um detetive calejado, lá sobrevive um ex-policial que conhece os truques de dentro, que os tiras sabem além de todos". (FEINMANN, 1975, p. 112)

Para Feinman, o modelo do romance policial é o do jogo a ser solucionado pelo pensamento lógico - tranquilizante operação da desordem e explicação para os fatos terríveis, em que "[...] todos os temores são expulsos e todas as perguntas são respondidas (FEINMANN, 1975, p. ). A solução é sempre lógica e acompanhada do senso de compreensão do detetive. Note-se que a imbricação entre o real e o imaginário se encontra num arquétipo literário, num tipo social de reverberação mundial, símbolo do herói aventureiro que aniquila o mal, personificado na figura do criminoso. Por tudo disso, Le Carré considera que "O moderno romance policial não existiria sem eles"8.

Nesse sentido citamos a matéria intitulada Sherlock. Holmes não é a mais alta expressão de poder investigador, escrita por Elysio de Carvalho, autor que recorrentemente era publicado pela revista, contudo, nas aventuras policiaes de Conan Doyle em que Sherlock Holmes - personagem vivificado-supostamente teria ficado contrariado ao ser colocado em segundo lugar numa classificação entre os profissionais na área de investigação criminal, quando comparado a Bertillon, considerado o primeiro. Holmes ficou, no entanto, em primeiro no tocante à sciencia pratica.

Anos 90, Porto Alegre, v. 21, n. 39, p. 257-284, jul. 2014 
E esclarece: "[...] assim Sherlock Holmes tem inveja da gloria justamente attribuida a Bertillon, que, seja dito desde já, na realidade excede ao heroe imaginário em saber, em imaginação e em perspicácia, comprovadas muitas vezes na sua longa carreira de perito policial"'. A sua referência a Sherlock comprova que o personagem suscita a ideia de que havia veracidade em suas ações e sua existência como um investigador, mesmo que a comparação tenha sido um chiste.

Coerentemente a tais julgamentos, na matéria de primeira página A luta contra o crime - o typo do 'detective'do século XX, Carvalho asssinalou a necessidade de uma polícia científica e judiciária como armas de combate contra o crime e defendeu que Holmes estava ultrapassado:

O typo do detective do século XX não é mais Lecoq. Todas as argúcias de Sherlock Holmes são velharias. Os Vidocq não têm mais razão de ser. A justiça para descobrir os crimes appella para o criminalista pratico, technico, o perito, versado em todos os conhecimentos, conhecendo o mundo dos malfeitores e seus costumes [...] O Crime, sob qualquer forma que se lhe apresente, não tem para elle segredos nem dificuldades, porque sabe tudo, mas tudo, realmente, quanto se refere á technica material dos delictos e à historia natural dos malfeitores. ${ }^{10}$

Também, em texto intitulado Os Crimes de Conan Doyle (De um livro inédito), assinada por uma inicial: M, havia ponderações positivas e negativas sobre autor. $\mathrm{O}$ assunto da nota era criticar o Conan Doyle, pois ele partia das circunstâncias do caso para a sua construção fruto de sua imaginação. A matéria da revista cita Patrocinio Filho que adensa ao comentário: “- Conan Doyle, descobre os crimes que elle mesmo comete" 11 .

Portanto, a crítica, além de reverberar no mundo literário, parece ser um alerta ao policial leitor, pois, para o autor, Doyle contribuiu para a "compreensão humana civilizadíssima da repressão ao crime"12. Apesar de ser um escritor do "grande público", não um "artista", legou um ideal, segundo a crítica da revista, de todo escritor de ficção "[...] a criação de um typo [...] a figura hoje universal de Sherlock Holmes, tirando para o modelo o detective norte-americano Pinkerton"13. 
Vida Policial: compreensão civilizadíssima da repressão ao crime...

Assim, historicizando o gênero, as balizas interpretativas e as figuras típicas de personagem do detetive na revista eram Edgard Allan Poe, o detetive Dupin, e de Arthur Conan Doyle, o detetive Sherlock Holmes. Poe, o gênio tenebroso, de tara hereditária, pai do conto de detetive, fundador do gênero e a figura universal da lógica dedutiva, Sherlock Holmes, autores e personagens citados e referenciados, modelos de conduta policial e de investigação.

\section{Os Êmulos de Rocambole do periodismo criminal}

Além dos modelares detetives, a influência da literatura policial sobre determinados tipos de indivíduos foi uma das discussões presentes no semanário. Pretendemos apresentar como se colocaram as questões sobre o combate ao crime, as determinações sobre o modo como o texto policial era apropriado, o papel do escritor e a influência da ficção na resolução de casos. Essas discussões pautavam-se em duas vertententes explicativas principais. Em primeiro lugar, da determinação negativa do texto policial, pois tornavam-se, nas mãos de degenerados leitores, perniciosa influência, e, em segundo lugar, a leitura do então chamado romance policial fez parte do processo de formação do policial e do criminologista.

No decorrer de sua publicação, a revista publicou algumas matérias que destacavam e explicavam como se operava a relação do que chamamos de educação às avessas, a influência danosa da literatura sobre os indivíduos, do referenciado pelo semanário como romance policial visto como manual do crime. $\mathrm{O}$ artigo publicado no número oito da revista, com o sugestivo título Romance policial, traz a temática como um problema ou caso, obviamente de polícia, nos seguintes termos:

Tem se argüido o romance policial não ser mais do que um manual do crime. [...] Esta literatura tem evidentemente seus lados perigosos, porquanto só tende a tornar interessantes os sinistros feitos dos indiciados que vivem à margem e que se transformam em heróes. ${ }^{14}$ 
Nessa matéria sobre o romance policial, discute-se o papel desses textos concebidos como "manual do crime", perigosos, que "ensinam" aos malfeitores. E também expõe a discussão sobre os métodos ideais de combate ao crime e ao criminoso naquele contexto. Os seus argumentos eram influenciados pela Escola Positiva e consideravam nesses termos que:

[...] um leitor já tarado, cujos instinctos perversos se acham despertados, deixar-se-há tanto mais captivar por essas aventuras extraordinárias quanto a sua curiosidade for superexcitada pela publicidade feita em torno dessas produções. Procurara exemplos dignos de ser imitados nos pormenores fornecidos pelo escriptor, reconstituirá as circumstancias descriptas, imaginara todas as scenas como se fossem verdadeiras e tirara do livro uma lição para seu uso. Pode-se objectar que elle a encontrara com uma influencia ainda mais mórbida nos jornaes que acompanham suas informações quotidianas de photographias suggestivas. ${ }^{15}$

E, assim, continua a matéria “[...] o romancista, demais disso, não 'é em geral senão o historiador de acontecimentos que elle toma 'à sua phantasia" "16. Então, o autor concebia os personagens, construía os "enredos criminais muitos notáveis, contudo seria excessivo fazê-los cúmplices dos factos que relatam”. O paralelo entre a escrita jornalística, a construção do que intitulavam o romance policial pelo escritor e os fatos criminais está explícito, mas o discurso o eximia de responsabilidade sobre o fato de que os degenerados espelhavam-se em suas estórias, ao contrário daqueles que os consideravam corresponsáveis e influenciadores na prática de crimes.

De fato, inúmeros foram os escritores que se basearam em crimes de ampla repercussão na construção de personagens e tramas, mas o tom presente na construção da frase em que o romancista é comparado ao historiador, que constrói o texto com o uso da fantasia, é de uma ambiguidade sui generis, pois se os fatos relatados inspiram e fornecem os meios de concretizar planos tortuosos, há veracidade e factibilidade no escrito. Além disso, 
Vida Policial: compreensão civilizadíssima da repressão ao crime...

[...] talvez que se devesse, ao contrario, ser-lhes [aos escritores] agradecido de muita vez haverem secundado a justiça na descoberta dos culpados que se acreditam ao abrigo da repressão. O criminologista aproveitou-se, em mais de um caso, do faro de Sherlock Holmes. Um dos mais hábeis dectetives de Nova York, o famoso inspector chefe Willian Burns, confessa francamente dever-lhe muito. ${ }^{17}$

Assim, percebe-se que o autor da matéria apresenta a leitura do romance policial como algo positivo, pois participava do processo de educaşão de um policial, um bom modelo a ser seguido. Apesar de essa matéria colocar-se contrária à visão de que o romance policial inspirava de modo direto e a todos os indivíduos na prática de crimes, em outros momentos, na revista, opinou-se de modo oposto, ou seja, reafirmando o caráter formativo, tanto deste tipo de escrito quanto do cinema. $\mathrm{O}$ argumento central era o pernicioso modelo, que ensinava a "ser bandido", também presente no cinema, na literatura em geral e na imprensa, transformados em "manuais do crime".

Esse artigo está editado logo após a matéria que contava a história e o papel da "Escola de Polícia Scientifica" do Rio de Janeiro, de 1912, que, segundo Elysio de Carvalho, era "um verdadeiro instituto de criminalística"18. O artigo exaltava a figura de Carvalho e a função das escolas de polícia como profissionalizadoras e preparadoras dos policiais em todas as áreas mais modernas e eficazes de combate ao crime. Aliás, questão sempre presente nos textos desse autor. Para nós, a relação entre a formação do criminologista e o papel que a literatura policial cumpria era dirigida também aos policiais que escreviam no semanário.

Já na matéria intitulada no semanário $A$ creança e o theatro, pelo Dr. Cláudio de Soura ${ }^{19}$ defenderam-se a difusão e o papel do teatro em sua função educativa, criticando-se, porém, essa relação no cinema. Outro texto similar foi chamado de $O$ cinematographo e a proteção a infância, P. Traddel, cujo objetivo era defender a censura e imposição de idade limite à entrada de crianças no cinema, devido à sua influência perniciosa. ${ }^{20}$ 
Em Meneghetti Emulo de Rocambole ${ }^{21}$, matéria sobre o "[...] larápio que revolucionou São Paulo nos últimos tempos", havia o reforço dessas ideias. Menechetti era um cérebro louco, doentio, de tara, um degenerado revoltado e possuía uma história de vida que reforçou a sua "convicção de ser victima da injustiça dos homens e da sociedade", responsável pelo que se tornou, conforme a matéria.

É que, segundo elle diz, desde a infância impuzeram-lhe castigos demasiados fortes, quando era ainda um criminoso primário capaz de uma inteira regeneração. Aos dezesseis anos, confessa haver praticado um pequeno delicto, conseqüência de sua pouca idade, loucura de criança: - castigaram-no com rigor, de modo excessivo - metteram-no em cárceres fechados em contacto com delinqüentes contumazes - ladrões, assassinos, anarchistas e vários outros, cuja promiscuidade fel-o um grande criminoso, sem o que - pensa elle poderia tornar-se um homem honrado, digno, útil a communhão social [...] Ia apenas executar o que aprendeu nas prisões diz elle - a roubar os ricos e fazer caridade aos pobres. Eis ahi a sua mentalidade, o producto das suas idéias. ${ }^{22}$

Nesse trecho, a alusão a Robin Hood é clara, similaridade com o ladrão nobre mais popular no mundo, sendo o seu papel social descrito de forma semelhante à de Menechetti: carreira criminal iniciada a partir de uma injustiça, roubava os ricos para dar aos pobres e tornou-se admirado por seus feitos fora da lei. (HOBSBAWM, 1976, p. 36-38) Hobsbawm, em Bandidos, analisou o universo do banditismo rural, sendo Robin Hood uma das imagens representativas da Justiça em oposição à opressão aos pobres em uma sociedade desigual rural. Contudo, seguindo análise desse autor, Menechetti era distinto, pois pertencia ao mundo urbano. (HOBSBAWM, 1976, p. 53). Tal qual Hood, Menechetti foi chamado pela imprensa de Príncipe dos Gatunos da América Latina, o maior ladrão conbecido de todos os tempos e um berói popular. (BERNARDI, 2000, p. 48) Na década de 20 do século XX, recebeu da imprensa o codinome de Émulo de Bonnot, célebre ladrão francês anarquista (HOBSBAWM, op. cit., p. 98). 
Vida Policial: compreensão civilizadíssima da repressão ao crime...

Destaque-se o subtítulo da matéria, logo em seguida da história de vida de Menechetti, supostamente narrada por ele mesmo, que foi chamada de Leituras perigosas. Nessa apresentam-se as leituras de muito gosto do célebre criminoso: panfletos anarquistas, escritos de Lênin, considerado "o seu farol", escritos sobre criminologia, autores como Lombroso, Ferri e Carrara, o código penal, que o tornou um "rábula temível" e finalmente que "amava romances policiaes" 23 . Desse modo, apresentou-se uma lista de obras, de leituras perigosas que supostamente o formaram para o aprendizado do mundo do crime, um conjunto de textos criminais: textos anarquistas, socialistas, de criminologia, jurisprudência e, claro, o complemento em que se ressalta uma emoção, o amor a um tipo de literatura, o romance policial. Vinculada a essa questão, aparece outra matéria sobre uma quadrilha de crianças ladras em São Paulo, chamada de "mão esfolada", cuja notícia foi intitulada Casos de hontem e de hoje - o cinema e os criminosos. Nessa reportagem, concebia-se o cinematógrafo como aquele que "proporciona as lições de cousas dadas", que "ensina petizes e marmanjos", pois

[...] o cinematographo é o melhor mestre que o antigo romance policial, que se transforma e não morre. Ensina pela imagem, não a imagem parada das estampas, mas a imagem em movimento, explicando os segredos da technica com uma clareza accessível aos mais broncos. É verdade que nas fitas a Polícia apparece também para atacar o crime, dando assim defeza à propriedade. Mas estas lições, parece, são menos proveitosas que as outras. $A$ Mão Esfolada já não precisa de folhear os livros para apurar os conhecimentos que lhe proporcionaram as fitas, e a mão da Polícia creio que só agora providenciara para que a maosinha da infância criminosa deixe de empalmar os bens alheios. ${ }^{24}$

Assim, o cinema era mais eficaz, pois o público mirim poderia, por meio dessa nova didática, aprender mais e melhor naquela que seria a sua vocação: o crime. Em outra matéria, O Cinema escola do crime - Milhares de creanças que se perdem em Lisboa desorientadas pelas perversas exbibições cinematográficas, assinada por José Barão, o cinema 
era considerado o foco da maldade e de perversão. ${ }^{25}$ Atingiria principalmente indivíduos, com indole perversa, que contraíram de seus pais as chamadas taras hereditárias e que estivessem inseridos em uma sociedade corrompida. A proposta do autor era a exclusão de filmes de influência nefasta: os films de aventuras, que deveriam ser substituídos pelos chamados films de arte, que aprimoram a sociedade e que a elevaria a "[...] degráos que a humanidade tem que trepar para chegar à perfeição maxima" ${ }^{\text {"26 }}$. E nesses termos apelativos afirmou:

Ignoram que os heroes rocambolescos dos films exercem uma nefasta influencia na psycologia dos jovens espectadores, que elles mais tarde hão de pretender praticar iguaes proezas que, fatalmente, os arrastarão para a viela da ignomínia, para o cárcere onde a sociedade - oh! Ironia! - os proscreverá do seu convívio. ${ }^{27}$

O termo rocambolesco tornou-se um adjetivo que derivou dos escritos de Ponson du Terrail, intitulado As proezas de Rocambole, o personagem principal, um herói popular de sua época. A sua narrativa é caracterizada pela utilização de lugares-comuns, que beiram atualmente à comicidade, repetitivas; contudo, mais precisamente: (MEYER, 2005, p. 104).

Pode-se então dizer que o termo rocambolesco não é somente um estereótipo definindo uma aventura descabelada, mas designa precisamente aquele conjunto de ações, conspirações, planejamentos por uma cabeça muito fria, de inteligência ímpar, para a urdidura da trama que permite, utilizando todos os talentos, todos os vícios, subornando, ameaçando, lançando mão do crime e da sedução, alcançar a qualquer preço, sem o menor excrúpulo, desconhecendo até a menção da moral, a única meta que interessa: dinheiro (MEYER, 2005, p. 120). 
Vida Policial: compreensão civilizadíssima da repressão ao crime...

Um texto sobre o tema foi o Tratamento do crime, de autoria de Rodrigues Dória, criminalista baiano, e nele a questão central eram as formas de conter o avanço do crime, em uma perspectiva medicalizada de instruir sobre "medidas therapeuticas aplicadas ou aplicáveis a esta espécie de moléstia, ou antes, a este defeito da sociedade - o crime", sendo que elas poderiam "ser prophylaticas ou preventivas, medidas palliativas, e medidas curativas" 28 . Entre essas medidas, o texto assinala o papel formativo da família para as crianças, dos exercícios físicos, da luta contra o alcoolismo, da volta dos indivíduos ao campo, da eliminação da tentação quanto à "ocasião que faz o ladrão", da educação e dos bons exemplos, além dos problemas da miséria e das doenças, como a tuberculose, que precisavam ser solucionados.

Nessa matéria ressaltou-se o papel de vários meios de difusão cultural, dos cinematógrafos, da literatura, dos "romances indecentes e immorais" e da imprensa. Em específico sobre o cinema, o autor afirmou que este poderia cumprir o papel de defesa da sociedade ou de incentivador do crime, ensinando como ser um criminoso, principalmente entre os espíritos fracos e degenerados. Já a imprensa, era considerada por ele como valorosa, mas também poderia causar grandes males, uma vez que "[...] no afan do mercantilismo se torna vehiculo de idéias nocivas e immoraes, com descrições escandalosas e perigosos anúncios, onde se vêem desfarçados o ensinamento e o estimulo para o crime". Assim, para solucionar o problema, seria necessária "uma direção moralisadora e salutar da imprensa e da litteratura são boas medidas para a contensão do crime" ${ }^{29}$.

A matéria criticava a publicação nos jornais dos grandes crimes, que, na opinião de Dória, tornava célebres os criminosos, e nos seguintes termos reforça as suas ideias:

Os romancistas exaltam as façanhas dos adversários de Sherlock Holmes e de Nick Carter, que rivalizam em audacia e astucia aos policiaes. Os modernos heroes malfazejos tem mais attracção para as almas jovens do que os personagens cavalerescos da condessa de Segur, de Julio Verne, ou de 
Femminore Cooper. Enfim, o film cinematographo mostra o apache escapando facilmente do gendarme. A imitação, este grande factor social, trabalha hoje em favor do crime. ${ }^{30}$

E, em Jose Ingenieros, ${ }^{31}$ importante médico argentino, publicado pela revista, essas questões estiveram presentes em um escrito, de 1920, chamado de Periodismo Criminal (RODRÍGUES, 2001). O tema do texto era a suposta sugestão criminosa, de apologia do periodismo criminal, o mais importante veiculo de sugestões, e que entre os presos se tornou uma cátedra para a aristocracia da infâmia, motivo de orgulho e meio de obter celebridade em sua carreira: "Porque o delinquente estimulado por seu orgulho, quer adquirir celebridade em sua carreira, pelas mesmas razões que o desejam o político e poeta, o sábio e o artista" ${ }^{2}$. Segundo o autor, apesar dos frequentes protestos dos moralistas e dos criminólogos, a imprensa era obrigada a completar a sua informação junto à maioria de seu público, considerado aquele caracterizado como popular de man gosto. Assim, os leitores honestos sentem uma repulsa e não são sugestionados, devido à orientação social de sua inteligência. Por outro lado,

Mas essas mesmas sugestões, levadas pela imprensa para a população penal, produzem o efeito oposto; encontram cérebros dispostos antisocialmente, propensos ao delito, por herança ou pela educação. Todo o crime é uma questão de emulação profissional, cada notícia, uma honra invejável, a lente fotográfica, ideal. Lendo o relato detalhado de um mesmo crime, o tranquilo burguês exclaramá: "Infâmia", e o delinquente comentará: "Magnífico golpe!" Como ignorar que as circunstâncias de exposição circunstanciada desses magníficos golpes deve ter grande influência sobre o espírito vaidoso dos criminosos? Essas apologias - para os insultos de jornalistas são elogios para os criminosos - não estimulam o seu orgulho profissional? (RODRÍGUES, 2001, p. 196).

Nesse sentido, o já citado escritor pioneiro do romance policial no Brasil, Medeiros e Albuquerque, teceu considerações sobre essa questão em seu diário de viagem. No trem entre Buenos Aires e Valparaíso, durante a elaboração de O mysterio, escreveu: 
Vida Policial: compreensão civilizadíssima da repressão ao crime...

A única coisa que me distraiu foi pensar num conto... No primeiro capítulo de O Mistério eu descrevi um crime bem-feito, que ninguém poderia descobrir. [...] Recentemente, em contos do Jornal do Brasil, eu descrevi um crime no Crime Impunido e outro em Implacável. Diante deles, várias pessoas me falaram da possibilidade de passar da teoria à prática. Outros me advertiram que eu estava dando ensinamentos perigosos. [...] Pensem que eu tenho passado estes dias ruminando o meu conto, devagarinho, por todas as faces, prevendo todas as objeções... Quem sabe quantos crimes impunes têm sido cometidos! O do meu conto, se fosse ou se for praticado, não falhará e não terá quem o descubra... O que eu não sei é se devo publicar o conto... (ALBUQUERQUE, 1979, p. 208-209).

O escritor Medeiros e Albuquerque achava-se certo de que na realidade, o crime cometido em seu conto poderia de fato inspirar e ser praticado por alguém. Sabe-se que o autor nunca publicou o seu texto, o que não se sabe se esse foi o motivo, mas percebe-se que nessa discussão estava presente, além da indissociabilidade entre a narração literária ficcional e a vida real, a possibilidade da impunidade que adviria de um crime perfeito obtido com base nos ensinamentos proporcionados pela literatura policial.

Igualmente, em propagandas de livros policiais e nas notícias de crimes, comparavam-se os criminosos aos personagens e às ações rocambolescas que surgiam nas obras de Doyle ou Poe, entre outros autores, como no texto de Elysio de Carvalho chamado Os crimes célebres - Enigma trágico: Miguel Trad, sobre um caso ocorrido em 1908, quando um indivíduo libanês matou o amante de sua mulher. Esse foi chamado de "o primeiro crime da mala", destaque na imprensa que despertou a imaginação pública e dos escritores de folhetim (FAUSTO, 2009. p. 40). O assassinato ocorreu da seguinte maneira: Trad, primeiramente, estrangulou a vítima, colocou-a em mala forrada com zinco e deslocou-se de trem a Santos, onde embarcou em navio com destino ao Rio de Janeiro. No trajeto, tentou jogar a mala ao mar, mas foi impedido por marinheiros que suspeitaram de sua atitude, pois podiam-se sentir os 
odores fétidos, que ele alegou ser de conservas podres. Quando a mala foi aberta, encontrou-se o corpo em estado de putrefação. Para Carvalho,

[...] em suma, o caso de Trad é, de algum modo o exemplo de drama judiciário, o mais phantastico, o mais singular e o mais intrincado que registra a chronica criminal do Brasil. N'elle se encontra o horror das novellas extraordinárias de Poe, a perversidade dos contos cruéis de Villiers e o mysterio tenebroso do drama shakespereano. ${ }^{33}$

E o autor ponderou ainda que "sem exagero, e também sem literatura, podemos dizer que Trad é uma esphynge, para nós uma esphynge... sem segredos" ${ }^{\prime 3}$. Assim sendo, para Carvalho, o caso de Trad, a motivação para o seu crime poderia ser interpretada analisando-o psicologicamente, Trad era um neurastênico e enfermo da vontade. Não obstante, no imaginário da época, havia um mistério não resolvido, pois o assassino nunca falou sobre o motivo do seu crime, e, assim, mais uma vez comparado à literatura, "[...] o caso foi um romance tenebroso de que se teria arrancado a ultima pagina para impedir ao leitor que conhecesse o final do enredo" 35 .

Além dessa interação da ficção com as histórias de crime, tanto quanto a inspiração para ser criminoso, correlacionava-se a inspiração para tornar-se policial, uma vez que na ficção referenciavam-se as ações dos investigadores como personagens-tipo, chamados de sherlocks, um referencial importante na forma de investigação dos detetives.

$\mathrm{Na}$ revista em diversas passagens comparou-se a ação de criminosos reais com a daqueles da ficção, como no caso de furto da "creada do capitalista de Copacabana", noticiado como "Uma ladra como as que apparecem nas historias de Sherlock Holmes mas a policia descobriu toda a astucia da rumena Paulina" ${ }^{\prime 36}$.

Nesse sentido, a matéria Os crimes que echoaram! Quadrilha Bonnot. O banditismo do século XX - Quando Bonnot e sua quadrilha alarmaram toda Paris ${ }^{37}$ discorre nos primeiros parágrafos sobre a ambiguidade dessa imprensa, que oscilava entre os caracteres positivos 
Vida Policial: compreensão civilizadíssima da repressão ao crime...

e negativos da ação do grupo; além do alarme generalizado para o avanço da violência e os novos métodos dos criminosos. Sublinha-se o início da matéria:

Neste século que allucina, pondo em choque os nervos do publico, um dos seus aspectos mais flagrantes é, sem duvida, o banditismo requintado de certos e determinados malfeitores que se celebrizam pela organização de seus bandos. [...] Depois das aventuras de "Lês Blancs et lês Bleus" de A. Dumas, que se lia em toda França, não se teve notícia, até hoje, num paiz de alta civilização, de uma quadrilha mais perversa, nem mais "modernamente" organizada. [...] Os personagens celebres dos romances de Maurice Leblanc, Maurice Level, Conan Doyle, etc., são reduzidos a simples brinquedos de creança, são modestos ladrões, deante dos seis indivíduos que, em automóvel, armados com revolvers e carabinas, cometteram, em França, os mais horripilantes episódios de latrocínio. ${ }^{38}$

A quadrilha atuou no ano de 1912, no norte da França, assaltando bancos e fazendo inúmeros mortos. A polícia ficou mobilizadíssima, entrando em ação com os seus "melhores agentes" no encalço do bando que conseguia "prodigios de envergonhar Sherlock Holmes", mas a polícia, por meio de trucs engenhosos, prendeu e matou alguns elementos da quadrilha. A matéria afirma que o líder Bonnot somente foi preso depois de um cerco que envolveu a polícia, mas também de "[...] populares, operários e campônios, em verdadeiras trincheiras, teve que destruir a dynamite a casa em que se alojára Bonnot".

Acompanham a matéria fotografias de indivíduos que pertenciam ao grupo, da casa implodida onde se escondera o líder, das barricadas de "populares" e dos policiais, de um carro utilizado pela quadrilha, de policiais conduzindo membros do bando e da prisão onde foram recolhidos os latrocidas. Ao final, os sobreviventes dessa caçada foram condenados à morte por meio da guilhotina.

Ao final da matéria, o editor afirmava que Vida Policial' iniciava um retrospecto de crimes celebres para o elucidamento de seus leitores e rememoração dos apaixonados da criminologia", 
e frisava que "[...] realidade é, quase sempre, superior à imaginação do homem, à ficção, enfim [...]" e que desse modo reavivariam "crimes de sensação", "incríveis e horripilantes". Estas duas últimas palavras carregadas de significado marcam a polarização e ambiguidade da descrição em sua mensagem: de um lado, o requinte, o moderno, o célebre, o incrivel e o sensacional, de outro, o perverso, o horripilante e o pavoroso.

O suposto paroxismo que envolve essas questões pode ser encontrado em matérias como O Rocambole dos Nossos tempos, em São Paulo. Como se chega a ser célebre na pratica do crime ${ }^{39}$; e $A$ alma encantadora e bárbara do Rio, matéria que contém a biografia e entrevista com malandros famosos, que pode ser percebida como uma forma celebrização da delinquência. ${ }^{40}$

No conto de Conan Doyle O funil de couro ${ }^{41}$, a questão da realidade que supera a fantasia no quesito horror esteve presente, além da celebrização de uma assassina. Na estória, inicialmente, o narrador é convidado por amigo parisiense, já morto, para hospedar-se em sua casa, em 1882. O francês chama-se Lionel Dacre, rico, morador de mansão, excêntrico, colecionador de obras de arte sobre o Talmud, cabala e magia: "Inclinado do monstruoso ao maravilhoso", fez os "peores excessos da missa negra" em sua casa. Conheceu-o quando pesquisava na seção assíria no Museu Britânico.

No quarto onde se hospedou, havia entre a profusão de objetos de colecionador um curioso objeto, um funil que chamou a sua atenção. Então o hóspede quer saber a história do objeto e seu anfitrião diz que ele o saberia caso dormisse tendo o funil ao lado de seu travesseiro. Mesmo não acreditando, o hóspede assim o faz. Sonha com uma mulher sofrendo a tortura da água com o funil. Comenta que se sentia aliviado por não estar na Idade Média. Relata o sonho a Dacre e este lê para ele os relatos da mulher que matara o pai e dois irmãos, um conselheiro do parlamento e o outro tenente civil, o relato é de dezesseis de julho de 1676. É o processo da Marqueza de Brinvilliers "uma das mais célebres criminosas da história" "42. Dacre revela ainda que o funil lhe fora dado como "lembrança" chefe de polícia que gravou as iniciais da marquesa no objeto de tortura, que continha também marcas de suas mordidas. 
Vida Policial: compreensão civilizadíssima da repressão ao crime...

Adequado a esse caso, citemos Doyle em O Estudo em Vermelho, quando afirma que "onde não há imaginação, não há horror". Assim, este foi um dos métodos eficazes de produzir o horror, e reproduzido por inúmeros outros escritores e até mesmo cineastas, que ao longo do século XX disseminaram o gênero. Alfred Hitchcook aparece entre os seguidores dessa máxima.

E na sequência das matérias no mesmo número em que se publicou o conto, foi editado o texto Os crimes da Marqueza de Brinvilliers, um relato de sua história e punição. ${ }^{43}$ Nesse relato sobre a criminosa do século XVII, discorreu-se sobre a história da nobre que envenara a família, foi condenada à morte pelo Tribunal da Inquisição e, assim, tornou-se uma célebre criminosa no Brasil na década de 1920.

Esse conto de Conan Doyle foi retomado por outros autores, tais como Alexandre Dumas em Os crimes celebres: Envenenamentos, parricidios, assassinios ${ }^{44}$, bem como por Cesare Lombroso em $O$ Homem Delinquente. (LOMBROSO, 2007, p. 55), pois, para o autor, um criminoso dotado de instabilidade nata assemelhava-se à marquesa, que, entre outros assassinatos cometidos, matou o pai para vingar o amante, bem como assassinou para enriquecer os filhos.

Assim, literatos e criminologistas utilizaram os casos de crimes e criminosos reais para construírem perspectivas de análise fundadas na explicação das motivações e chegarem ao âmago da questão do delito, principalmente caracterizada na análise criminológica corrente do período, a Escola Positiva. Destaque para o processo de ficcionalização dessas histórias que propiciam a construção de narrativas espetaculares e sensacionais, bem ao entretenimento de época, necessariamente carregado de um imaginário formador e instrutivo ao leitor.

\section{Ficção e Realidade: o policial, o escritor e o jornalista}

O já citado Rodolph Archibald Reiss, como outros criminalistas e juristas, condenava a incitação propiciada pela imprensa ao veicular casos de criminosos que se tornavam famosos ao ser publicados pela imprensa, e reforçava a opinião corrente em meios criminalistas de ponta a partir da questão da criminalidade na Europa: 
A reclame feita em torno dos crimes sensacionais provoca um irresistível sentimento de vaidade e orgulho que muitas vezes leva à prática de um delito, alimentado pelas notícias impressionantes com que a imprensa explora habitualmente os grandes crimes e à custa das quais consegue ver aumentada de uma forma considerável a sua venda avulsa [...] $\mathrm{O}$ jornal moderno é uma empresa comercial como qualquer outra obrigada a procurar e sustentar à outrance os favores da sua clientela. O público procura avidamente sensações fortes, capazes de manter a vida de desequilíbrio nervoso que hoje se leva. O operário, cansado da labuta cotidiana, lê com prazer a descrição pormenorizada do crime do dia, que é discutido em família, fazendo-se presunções sobre a prisão do criminoso, as causas do delito etc. [...] Daí o poder afirmar-se que, dos leitores de um jornal, 95\% não conhecerão os nomes beneméritos de Pasteur, de Marconi ou de quaisquer outros cientistas, literatos, músicos etc. Mas certamente todos eles saberão que Bonnot, Garnier, Soudy eram grandes criminosos, e que Mme. Steinhel era acusada de ter matado o marido. ${ }^{45}$

A discussão do papel e da influência da literatura policial sobre os indivíduos, bem como de outras mídias, como a imprensa e o cinema foram pautadas frequentemente por meio de matérias específicas. Todavia, na revista, percebemos a existência de posicionamentos que ora afirmavam a nefasta influência do escrito criminal, ora defendiam que este tipo de literatura somente corromperia os propensos, os já degenerados - aqueles que, segundo a antropologia criminal, já tenderiam para o crime. (DARMON, 1991).

Por certo que nos textos chamados pelo semanário de romances policiais a construção do texto literário reverberava uma espécie de educação às avessas, pois as ações e os personagens eram parcialmente pautadas pelos ilegalismos, (FOUCAULT, 1977) vistos como forma de combate social ao crime mais aceitável e eficaz. Assim, a forma de investigação e solução dos crimes em muitos casos ocorria somente por meio da ação ilegal dos investigadores. 
Vida Policial: compreensão civilizadíssima da repressão ao crime...

Além disso, as ações e os meios de combate aos crimes, tidos como modelo ideal, perpetrados por agentes de segurança amadores - os detetives diletantes -, implicam a potência individual do supercérebro do investigador, de inteligência ímpar, que se expande e se consolida como modelo de ação de investigação, o super-herói, arquetípico, uma exemplaridade de vigilância, prevenção e segurança em sua totalidade.

Portanto, para pensar a questão do gênero literário policial na revista Vida Policial, faz-se necessário atentar para o fato de que objetivamente os contos e os folhetins eram a expressão do que deveria ser um policial, e apesar de nem sempre apresentarem um aspecto positivo destes, a própria crítica ou os ilegalismos posicionam e direcionam para o seu complementar ou oposto.

Além disso, a literatura policial operou com informações e fatos da escrita policial jornalística, sendo a inserção do escritor nos meios criminais uma das formas de obtenção de caracteres para personagens e tramas. A citação abaixo exemplifica bem esta ideia:

- Traz-me algum bello crime, cuja trama possa servir para um romance sensacional de grande tiragem?

- Ainda não sei, sr. Parent. Entretanto, pode ser. Mas, em todo o caso, eu venho apellar para as suas luzes para decifrar um mysterio muito turvo. [...] Vós outros, romancistas, possuem o espírito inventivo, a imaginação que nos falta. O senhor agora conhece o crime, poderá encontrar um móvel? ${ }^{46}$

Nesse diálogo escrito pelo romancista Woestyn, o personagem Richard Parent, também escritor, descrito como muito conhecido, com policial Pinson, inspetor de policial, foi parte do conto intitulado Um crime extranho - o mysterio dos narcisos negros. Neste caso um crime que é qualificado como belo e sensacional proporcionaria uma grande tiragem; contudo, para o investigador, o escritor era o canal de obtenção da solução do crime, pois a imaginação e o espírito inventivo eram as qualidades necessárias para solucionar o caso, inter-relação inventiva e solucionadora de casos, quase tautológica. 
Então, por vezes, os policiais obtinham estórias que informavam os modelos de boa polícia e os escritores precisavam de policiais que relatassem os crimes minunciosamente para a criação de novelas policiais. Também era uma relação triangularizada na medida em que incluímos o jornalismo policial como um dos meios que a circulação de métodos e tramas policiais opera na inter-relação entre a fiç̧ão e realidade.

Assim, de forma geral, percebe-se que houve ambiguidades e tensões no semanário inserido no debate sobre o papel do que a revista chamava de romance policial. Por um lado, o valor do pedagógico explicitado a partir do conto e folhetim como a serviço da polícia, auxiliando-a no combate ao crime; por outro, as críticas à sua possível ação pedagógica para o bandido, ensinando-o a cometer um crime. Contudo, também esteve presente implicitamente a questão da espetacularização do crime e do criminoso que se tornam temas de matérias de todos os gêneros na revista, inclusive utilizando uma série de representações imagéticas.

\section{VIDA POLICIAL: UNDERSTANDING HIGHLY CIVILISED CRIME REPRESSION AND (OR) INFLUENCE IN YOUNG'S PEOPLE PSYCHOLOGY}

Abstract:This paper analyzes the tales and detective feuilletons published in the magazine Vida Policial, in the city of Rio de Janeiro (1925-1927). The weekly published police chronic, tales, serial, police doctrine, texts of the legal world as well as news reporters. The police written were means of building types of crime and criminal, at the same time all this produced a social imaginary which imputed to this type of literature, the stigma of a crime handbook. Reproduced in police writtens what we call education in reverse, because the actions and characters printed with the mark of illegalism a form of social struggle more acceptable and effective. Actions and means and combat the crime, seen as the ideal model, perpetrated by security agents amateurs - amateurs detectives imply the individual power of the investigator, as Sherlock Holmes, which has established itself as the superhero archetype, an exemplary surveillance, prevention and safety.

Keywords: Police magazine. Crime and midia. Detective feuilletons. 
Vida Policial: compreensão civilizadíssima da repressão ao crime...

\section{Notas}

${ }^{1}$ As suas obras chegaram a Europa por intermédio de autores como Baudelaire.

${ }^{2}$ Também, de modo incisivo, na poesia, dada a quantidade de traduções de $O$ corvo.

${ }^{3}$ VIDA POLICIAL, n.50, p.22-28, 20 fev. 1926.

${ }^{4}$ VIDA POLICIAL, n.45, p.11, 16 nov. 1925.

${ }^{5}$ VIDA POLICIAL, n.45, p.11, 16 nov. 1925.

${ }^{6}$ VIDA POLICIAL, n.45, p.11, 16 nov. 1925.

${ }^{7}$ DARMON, 1991, p.194-197; Ver também CARRARA, 1998. p.81-89.

${ }^{8}$ Citado por John Le Carré em Introdução de DOYLE, op. cit., p.12.

${ }^{9}$ VIDA POLICIAL, n.34, p.5, 1925.

${ }^{10}$ VIDA POLICIAL, n.42, p.1, 1925.

${ }^{11}$ VIDA POLICIAL, n.2, p.8, 1925.

${ }^{12}$ VIDA POLICIAL, n.2, p.8, 1925.

${ }^{13}$ VIDA POLICIAL, n.2, p.8, 1925.

${ }^{14}$ VIDA POLICIAL, n. $8,1925$.

${ }^{15}$ VIDA POLICIAL, n.8, p.19, 1925.

${ }^{16}$ VIDA POLICIAL, n.8, p.19, 1925.

${ }^{17}$ VIDA POLICIAL, n.8, p.19, 1925.

${ }^{18}$ VIDA POLICIAL, n.8, p.18, 1925.

${ }^{19}$ VIDA POLICIAL, n.77, 1926.

${ }^{20}$ VIDA POLICIAL, n.77, 1926.

${ }^{21} \mathrm{O}$ termo rocambolesco tornou-se um adjetivo que derivou dos escritos de Ponson du Terrail (1820-1871), intitulado As proezas de Rocambole, o personagem principal, um herói popular de sua época. A sua narrativa é caracterizada pela utilização de lugares-comuns, que beiram atualmente à comicidade, repetitivas. Também, "Cheio de peripécias e aventuras inverossímeis; enredado; enrolado: uma estória rocambolesca; uma fuga rocambolesca" (DICIONÁRIO Unesp do Português Contemporâneo. São Paulo: Editora da UNESP, 2004. p.1228).

${ }^{22}$ VIDA POLICIAL, n.29, p.24, 1925.

${ }^{23}$ VIDA POLICIAL, n.74, 1926. (Sem grifos no original).

${ }^{24}$ VIDA POLICIAL, n.29. p.24, 1925.

${ }^{25}$ VIDA POLICIAL, n.46. p.20, 1926.

${ }^{26}$ VIDA POLICIAL, n.46. p.21, 1926.

${ }^{27}$ VIDA POLICIAL, n.46. p.21, 1926.

${ }^{28}$ VIDA POLICIAL, n.70, 1926.

${ }^{29}$ VIDA POLICIAL, n.70, 1926.

${ }^{30}$ VIDA POLICIAL, n.70, 1926.

${ }^{31}$ Do autor encontramos na revista a matéria intitulada $O$ delicto e a pena diante da filosofia biológica - Pelo Dr. José Ingenieros. (VIDA POLICIAL, n.12, p.2-6, 1925). 
${ }^{32}$ Ibid., p.196.

${ }^{33}$ VIDA POLICIAL, n.34, p.3, 1925.

${ }^{34}$ VIDA POLICIAL, n.34, p.3, 1925.

${ }^{35}$ VIDA POLICIAL, n.34, p.3, 1925.

${ }^{36}$ VIDA POLICIAL, n.12, p.40, 1925.

${ }^{37}$ VIDA POLICIAL, n.2, p.51-53, 1925.

${ }^{38}$ VIDA POLICIAL, n.2, p.51, 1925.

${ }^{39}$ VIDA POLICIAL. Rio de Janeiro, n.75, 1926.

${ }^{40}$ VIDA POLICIAL, n.72, 1926.

${ }^{41}$ VIDA POLICIAL, n.62, 1926.

${ }^{42}$ VIDA POLICIAL, n.62, 1926.

${ }^{43}$ VIDA POLICIAL, n.62, 1926.

${ }^{44}$ EXPOSIÇÃO virtual da Biblioteca Nacional de Portugal intitulada Antes das Playstations: 200 Anos do Romance de Aventuras em Portugal inaugurada em 22 de outubro de 2003. Disponível em: < http://purl.pt/301/1/dumas-resumos/crimes-celebres.html>. Acesso em: 11 jan. 2011.

${ }^{45}$ A GAZETA, 11 set. 1913 apud BERNARDI, 2000, p.44.

${ }^{46}$ VIDA POLICIAL, n.45, p.9, 1925.

\section{Referências}

ALBUQUERQUE, Paulo de Medeiros. O mundo emocionante do romance policial. Rio de Janeiro: Francisco Alves, 1979.

BERNARDI, Célia de. O lendário Meneghetti. São Paulo: Annablume, 2000.

COSTA, Flávio Moreira da Os cem melhores contos de crime e mistério da literatura universal. Rio de Janeiro: Ediouro, 2002.

CARRARA, Sergio. Crime e loucura: o aparecimento do manicômio judiciário na passagem do século. Rio de Janeiro: EdUERJ; São Paulo: EdUSP, 1998.

DARMON, Pierre. Médicos e assassinos na Belle Époque: a medicalização do crime. Rio de Janeiro: Paz e Terra, 1991.

DOYLE, Sir Arthur Conan. Um estudo em vermelho. São Paulo: Martim Claret, 2003b.

- As aventuras de Sherlock Holmes: um escândalo na boêmia e outras histórias. Porto Alegre: L\&PM, 2003a.

Sherlock Holmes. Edição definitiva, comentada e ilustrada. Rio de Janeiro: Jorge Zahar, 2005. v.1.

Anos 90, Porto Alegre, v. 21, n. 39, p. 257-284, jul. 2014 
Vida Policial: compreensão civilizadíssima da repressão ao crime...

ECO, Umberto; SEBEOK, Thomas A. O signo de três. São Paulo: Perspectiva, 2004. FAUSTO, Boris. O crime do restaurante chinês. São Paulo: Companhia das Letras, 2009. FEINMANN, Jeffrey O mundo misterioso de Agatha Christie. Rio de Janeiro: Record, 1975.

FOUCAULT, Michel. Vigiar e punir. Petrópolis: Vozes, 1977. . Em defesa da sociedade: curso no Collège de France (1975-1976). São Paulo: Martins Fontes, 1999.

HAINING, Peter. The classic era of crime fiction. Chicago: Chicago Review Press, 2002. HARROWITZ, Nancy. O arcabouço do modelo de detetive organizador. In: ECO, Umberto; SEBEOK, Thomas A. O signo de três. São Paulo: Perspectiva, 2004. HOBSBAWM, Eric J. Bandidos. 2. ed. Tradução de Donaldson Magalhães Garschagen. Rio de Janeiro: Forense-Universitária, 1976.

LOMBROSO, Cesare. O homem delinqüente. São Paulo: Ícone, 2007.

McLUHAN, Marshall. Como se lee el policial: lógica narrativa y mercado. In: LINK, Daniel (Org.). El juego de los cautos: literatura policial: de Edgar A. Poe a P. D. James. Buenos Aires: La Marca, 2003.

MENDES, Oscar. Influência de Poe no estrangeiro. In: POE, Edgar Allan. Fição completa, poesia e ensaios. Rio de Janeiro: Nova Aguilar, 1986.

MEYER, Marlyse. Folhetim: uma história. São Paulo: Companhia das Letras, 2005. RODRÍGUES, Esteban (Org.). Periodismo criminal. In: Contra la prensa: antologia de diatribas y apostillas. Buenos Aires: Colihue, 2001.

REVISTA VIDA POLICIAL, Rio de Janeiro, 1925-1927. Biblioteca Nacional do Brasil.

Recebido em: 30/07/2012.

Aprovado em: 11/04/2013. 